\title{
ANKRD24 wt Allele
}

National Cancer Institute

\section{Source}

National Cancer Institute. ANKRD24 wt Allele. NCI Thesaurus. Code C150170.

Human ANKRD24 wild-type allele is located in the vicinity of 19p13.3 and is approximately $42 \mathrm{~kb}$ in length. This allele, which encodes ankyrin repeat domain-containing protein 24 , is involved in protein-protein interactions. 